\title{
Perceptions of Organizational Politics: A Meta-Analysis of Its Attitudinal, Health, and Behavioural Consequences
}

\author{
Akanksha Bedi \\ California State University, Northridge \\ Aaron C. H. Schat \\ McMaster University

\begin{abstract}
In this study, we report the results of a meta-analysis of the relations between perceptions of organisational politics (POP) and attitudinal, psychological health, and behavioural variables using data from 118 independent samples, totaling 44,560 participants. Among the variables examined, POP was most strongly related to organisational trust and interactional justice, but also exhibited relations with a variety of other criteria, including positive relations with stress, burnout, turnover intentions and counterproductive work behaviour, and negative relations with job satisfaction, citizenship behaviour, and job performance. We also found evidence that some effect sizes were moderated by the publication status, geographical origin of data, and types of measures used to assess POP.
\end{abstract}

Keywords: perceptions of organisational politics, stress, job satisfaction, absenteeism, organisational trust

It has been about 25 years since Ferris, Russ, and Fandt (1989) introduced their seminal model of perceptions of organisational politics (POP) and more than a decade since it was revised and updated by Ferris, Adams, Kolodinsky, Hochwarter, and Ammeter (2002). Since that time, researchers have used these models to guide their investigations of the antecedents, correlates, and consequences of perceptions of politics in work settings. Reviews of this literature have generally shown that politics is influenced by a variety of individual attributes, such as Machiavellianism, positive affectivity, and locus of control, and conditions in the work environment, such as job autonomy, centralization, and formalization (e.g., Ferris et al., 1989; Hochwarter \& Thompson, 2010; Valle \& Perrewe, 2000). In addition, research has shown that individuals who perceive politics at work experience negative outcomes; for example, lower levels of job satisfaction and commitment and higher levels of job stress (e.g., Atinc, Darrat, Fuller, \& Parker, 2010; Miller, Rutherford, \& Kolodinsky, 2008).

Although Ferris et al.'s (2002, 1989) framework has been useful in advancing the understanding of the nomological network of POP, much of the empirical research on the construct has focused on its proposed consequences. Given this, the primary purpose of the present meta-analysis was to contribute to our understanding of, and guide future research on POP by

Akanksha Bedi, Department of Management, California State University, Northridge; Aaron C. H. Schat, DeGroote School of Business, McMaster University, Hamilton, Ontario, Canada.

A preliminary version of this meta-analysis was presented at the annual meeting of the Society of Industrial and Organizational Psychology, San Francisco, California, April 10-12, 2008.

Correspondence concerning this article should be addressed to Akanksha Bedi, Department of Management, California State University, Northridge, 18111 Nordhoff Street, Northridge, CA 91330. E-mail: abedi@csun.edu (a) representing, as accurately as possible given the available data, the relations between POP and its theoretically proposed consequences; and (b) investigating whether these relations are moderated by methodological or other variables.

Using insights from the job demands-resources (JD-R) theory (Bakker \& Demerouti, 2007; Demerouti, Bakker, Nachreiner, \& Schaufeli, 2001), we propose organisational politics as a job demand that requires employees to expend sustained physical and/or psychological effort to manage, resulting in various negative attitudinal, psychological health, and/or behavioural consequences. Past reviews by Chang, Rosen, and Levy (2009) and Miller, Rutherford, and Kolodinsky (2008) have helped to integrate segments of the literature on POP but focused on a narrower set of individual outcomes than were examined in this meta-analysis. For instance, Miller et al. (2008) focused specifically on job satisfaction, stress, job performance, turnover intentions, and organisational commitment, while Chang et al. (2009) focused on strain, job satisfaction, turnover intentions, organisational citizenship behaviours-individual (OCB-I), organisational citizenship behaviours (OCB-O), task performance, and affective commitment. Our goal with the present research is to extend and update previous reviews in three ways. First, we analyse a broader range of variables that have been theoretically positioned as consequences of POP. In addition to the variables included in previous studies, we also include variables such as absenteeism, counterproductive work behaviours, self- and supervisor-rated job performance, burnout, job involvement, organisational trust, organisational support, perceived work control, distributive justice, interactional justice, and procedural justice. Second, we include more samples than previous reviews (118 in the present work compared with 70 in Miller et al. and 79 in Chang et al.). Finally, we extend the moderator analyses of these previous studies by including an additional moderator (type of POP measure) and by applying the moderator analyses to a larger dataset and to a wider range of variables' relations with POP. 


\section{Theoretical Background}

According to Ferris, Harrell-Cook, and Dulebohn (2000), POP is defined as an individual's subjective appraisal of the extent to which the work environment is characterised as self-serving of various individuals and groups, to the detriment or at the cost of other individuals or groups. This definition has two important features. First, POP is a perceptual variable that represents an individual's personal evaluation of the behaviour they witness and experience in their work environment. Although it is recognised that these perceptions may not reflect objective reality (Ferris et al., 1989; Gandz \& Murray, 1980), because they represent an individual's view of reality, these perceptions will influence an individual's cognitive, emotional, and behavioural responses (Ferris et al., 2002). Second, the behaviour that comprises POP is behaviour that is deemed to be self-serving and that occurs at the expense of others in the organisation.

Much of the research on POP has been centered around Ferris et al.'s (1989) model of the antecedents and consequences of politics perceptions. Research on the consequences of POP shows that it is associated with a variety of dysfunctional attitudinal, psychological health, and behavioural outcomes. These include reduced job satisfaction (e.g., Cropanzano, Howes, Grandey, \& Toth, 1997), organisational commitment (e.g., Harris \& Kacmar, 2005b), job involvement (e.g., Ferris \& Kacmar, 1992), stress, burnout (e.g., Vigoda \& Kapun, 2005), job performance, and citizenship behaviours (e.g., Randall, Cropanzano, Bormann, \& Birjulin, 1999), as well as increased levels of absenteeism (e.g., Vigoda, 2000), turnover intentions (e.g., Valle \& Perrewe, 2000), and counterproductive work behaviours.

The link between POP and its outcomes can be explained by using the perspective offered by the JD-R model (Bakker \& Demerouti, 2007; Demerouti et al., 2001). The JD-R model suggests that employee well-being is influenced by two specific characteristics of the work environment: job demands and job resources (Demerouti et al., 2001; Schaufeli \& Bakker, 2004). In this article, we focus on the former, as we are positioning POP as a job demand. Job demands refer to those physical, social, or organisational aspects of the work context that require sustained physical and/or psychological effort and are, therefore, associated with physiological (e.g., insomnia) and/or psychological costs (e.g., burnout). Examples include high workload, poor environmental conditions, and-more directly relevant to this articleperceptions of politics in one's workplace. (Demerouti et al., 2001). A politically charged work environment is characterised by uncertainty and ambiguity where favoritism and self-serving behaviours are prevalent (Kacmar \& Ferris, 1991). Work environments characterised by such norms require employees to be vigilant about the behaviour of others to protect their reputations and status in the organisation. This vigilance taxes employees' affective, cognitive, and physical resources, which manifests in attitudinal, behavioural and psychological health consequences.

\section{Attitudinal Consequences of POP}

Using the JD-R framework, we hypothesise a negative relation between POP and its attitudinal outcomes, which include job satisfaction, job involvement, organisational commitment, and perceived work control. In a politicised work environment, employees may feel more susceptible to the political behaviour of others, diminishing their sense of control. Moreover, to manage the politicised environment, they may feel compelled to engage in impression management tactics, which would distract them from their job related duties and undermine their motivation and job satisfaction (Lepine, Podsakoff, \& Lepine, 2005; Rosen, Harris, \& Kacmar, 2009). Moreover, frustrated by their inability to control and fulfill their work responsibilities, some employees might attempt to cope with the situation by mentally distancing themselves from their work, others at work, and the organisation itself, leading to decreased attachment and identification with the organisation (Folkman \& Lazarus, 1985; Lepine et al., 2005).

Hypothesis 1: Perceptions of organisational politics is negatively associated with (a) job satisfaction, (b) job involvement, (c) organisational commitment, and (d) perceived work control.

Fair treatment represents a resource that induces a mutual trust and level of support between the source of this fair treatment and its target (Stinglhamber, De Cremer, \& Mercken, 2006). A work environment characterised by politics is an environment in which fair processes and outcomes are more likely to be disregarded by those who are pursuing their own agendas and self-interest. Working in such an environment would require employees to be more vigilant to ensure their interests are not compromised by the behaviour of others. This vigilance depletes cognitive and emotional resources and would also undermine one's perceived justice, particularly procedural justice. Moreover, it would also make employees more suspicious of the intentions and behaviours of other employees, and therefore, more likely to experience lower levels of trust, fairness, and support.

Hypothesis 2: Perceptions of organisational politics is negatively associated with (a) organisational justice, (b) organisational trust, and (c) organisational support.

\section{Psychological Health Consequences of POP}

POP is also expected to associate with perceived stress, burnout, and other indicators of psychological ill health (Bakker, Demerouti, \& Verbeke, 2004; Schaufeli \& Bakker, 2004). One of the crucial propositions of the JD-R model is that burnout or stress develop because of (a) high job demands that deplete an individual's mental and physical resources, and (b) the absence of job resources, which reduces motivation and results in cynicism and frustration (Demerouti et al., 2001). A political work climate is characterised by features such as backstabbing, favoritism, and uncertainty. As we suggested earlier, protecting oneself from these behaviours requires vigilance, which can deplete employees' cognitive and emotional resources. With these resources diminished, employees are more likely to feel less equipped to manage their work demands, leading to perceived stress and burnout (Hemingway \& Smith, 1999; Wong \& Law, 2002).

Hypothesis 3: Perceptions of organisational politics is positively associated with (a) burnout and (b) stress.

\section{Behavioural Consequences of POP}

Theoretical and empirical work has identified several behavioural outcomes of POP, including performance and citizenship 
behaviour (for reviews, refer to Ferris et al., 2002, 1989). In this study, we propose a negative relation between POP and its behavioural outcomes, such as performance and citizenship behaviours. From the perspective of JD-R theory, dealing with the demands of a political work environment-whether it is dealing with the anxiety produced by the politics or "watching one's back"directs employee attention and energy away from performing their job responsibilities or engaging in citizenship behaviour.

The negative relationship between politics and performance can also be explained with self-determination theory (SDT). According to SDT, people are intrinsically motivated when social-contextual factors aid them in successfully satisfying their needs for competence, relatedness, and autonomy (Deci \& Ryan, 1985). A political work climate impedes the processes underlying competence, relatedness, and autonomy, resulting in reduced intrinsic motivation. Specifically, organisations where decisions are influenced by political maneuvers and where power and control are concentrated in the hands of few individuals diminish employees' feelings of competence and autonomy. In addition, employees have to continuously monitor, control, and change their self-presentations to conform to the norms of the political environment, thus resulting in alienation and reduced levels of relatedness. In other words, politics may signal to employees that their work performance is not self-determined but is dependent on the decisions of few powerful others. This could negatively affect their intrinsic motivation and work performance (Ryan \& Deci, 2000). In such work settings, employees may try to cope with the situation by avoiding or exiting the political environment thus resulting in increased counterproductive and withdrawal behaviours, such as absenteeism and turnover intentions (Folkman \& Lazarus, 1985; Rodell \& Judge, 2009; Wallace, Edwards, Arnold, Frazier, \& Finch, 2009).

Hypothesis 4: Perceptions of organisational politics is negatively associated with (a) job performance and (b) organisational citizenship behaviours.

Hypothesis 5: Perceptions of organisational politics is positively associated with (a) absenteeism, (b) turnover intentions, and (c) counterproductive work behaviours.

\section{Potential Moderators}

In addition to various predictors and outcomes of POP, the current meta-analysis tests whether the variance in the relations observed across studies can be explained by methodological or other characteristics (i.e., moderators). The following moderators were investigated in the present study.

\section{Publication Bias}

According to Rosenthal (1979), studies producing nonsignificant or unexpected results are less likely to be published. Publication bias therefore presents a serious threat to validity as it may result in inaccurate estimates of the relations in question. In the current study, we tried to assess the presence of this concern by obtaining unpublished studies from researchers who had authored studies in POP and from unpublished doctoral dissertations, and then comparing the data of published versus unpublished studies.

\section{Geographical Location}

Past research has raised the possibility that cultural differences may result in differential relations between POP and its outcomes (Vigoda-Gadot, 2000, 2001). To assess the degree to which the relations in our model generalise to countries outside of North America, we examined whether the geographical location where the study was conducted accounts for significant differences in effect sizes. Because relatively few studies were available from outside of the United States and Canada, we could not do specific country comparisons and so we categorised countries into two groups: North America versus outside of North America. The few non-North American samples in our database come from countries that are considered more collectivistic than Canada and the United States (e.g., Israel, China). In collectivistic cultures employees are more concerned with maintaining group conformity and harmonious relationships with others than the pursuit of personal goals (Erdogan, Kraimer, \& Liden, 2004). Therefore, employees in these cultures may be more tolerant of and therefore, less sensitive to and adversely affected by, workplace politics. In contrast, employees in individualistic countries-such as Canada and the United States-prefer higher levels of process control (i.e., voice) and are more likely to be adversely affected by political behaviour.

\section{Measurement of POP}

Given the substantial variety in the number of measurement instruments for POP, it is possible that inconsistent results in POP research are attributable, in part, to different operationalizations. A majority of the research on POP has used three measures: Kacmar and Ferris's (1991) original POP scale; Kacmar and Carlson's (1997) revised POP measure; and Hochwarter et al.'s (2003) 6-item measure. Thus, our comparisons are between these three measures.

\section{Method}

\section{Literature Search}

A fivefold approach was used to locate studies for the metaanalysis. First, we conducted a computerised bibliographic search of PsycINFO, ABI/INFORM, and Dissertation Abstracts International by using the terms organisational politics, workplace politics, politicized environment, POPS, and perceptions of organisational politics. Second, the reference lists of retrieved articles were reviewed to identify additional citations. Third, manual searches of the conference programs and proceedings for Society for Industrial and Organisational Psychology, Administrative Sciences Association of Canada, and Academy of Management conferences were carried out to identify unpublished articles. Finally, frequent contributors to the organisational politics literature were contacted with requests for copies of any unpublished or in-press articles. These processes identified over 154 conceptual and empirical publications, unpublished works, dissertations, books, and book chapters. An additional search on Google Scholar revealed 3 studies in Chinese, all of which were coded with the assistance of a Chinese translator. 


\section{Criteria for Inclusion/Population of Interest}

To be included in our analyses, a study had to report a correlation coefficient or other effect size between perceptions of organisational politics and another variable. In addition, studies had to report sample sizes along with other pertinent information (e.g., reliability values) that allowed for the computation of effect sizes. Finally, when multiple studies presented data from the same or overlapping samples, we included only the data from the study including the largest sample. Using the above criteria, we identified a total of 118 independent samples involving 44,560 employees. Of these samples, 84 were from published journal articles, 20 were from unpublished dissertations, 11 were from published book chapters, and 3 were from a paper presented at a conference.

\section{Coding of Studies}

For each study, statistics coded included sample size, correlation coefficients, reliability values, $t$ tests, or $F$ tests. In addition, we coded for several potential moderators in our study, namely, published versus unpublished, geographical location, and the measurement instrument used to assess POP. The first author was responsible for coding variables. To assess the reliability of this coding, a random sample of 19 studies (i.e., 22\%) was independently coded by the second author. We exhibited $90 \%$ agreement on measure type and $100 \%$ agreement on publication status and study location. Any initial differences in coding were resolved via discussion until agreement was reached.

\section{Meta-Analytic Procedures}

The Hedges and Olkin (1985) meta-analytic technique was used for the analyses. We only included variables for which there were at least three correlations with POP available from independent samples. Correlations were corrected for unreliability using the reliability estimates reported for each sample. When reliabilities were not reported, we used the sample-size weighted mean reliability from the studies that reported reliabilities (Table 1). Each corrected $r$ was transformed using the Fisher $Z$ transformation of $r$ to normalise the distribution. The means of the Fisher $Z$ transformed $r$ s were then calculated by weighting the effect sizes by their inverse variance to account for the different sample sizes on which each effect size was based. The overall weighted average

Table 1

Reliability Estimates Used in the Meta-Analysis Calculations

\begin{tabular}{lrrr}
\hline \multicolumn{1}{c}{ Variable } & $k$ & $N$ & $r_{x x}$ \\
\hline Organizational politics & 113 & 42,807 & 0.82 \\
Organizational support & 12 & 3,211 & 0.90 \\
Procedural justice & 10 & 2,688 & 0.92 \\
Job satisfaction & 55 & 21,848 & 0.86 \\
Job involvement & 5 & 3,291 & 0.82 \\
Continuance commitment & 9 & 3,657 & 0.74 \\
Organizational citizenship behaviors & 19 & 8,410 & 0.85 \\
Turnover intentions & 31 & 11,673 & 0.76 \\
Job stress & 24 & 7,318 & 0.80 \\
\hline
\end{tabular}

Note. $k=$ the number of samples providing reliability information; $N=$ total number of individuals in $k$ samples; $r_{x x}=$ mean reliability of each variable across $k$ samples.
Fisher $Z$ transformed $r$ s were then converted back to " $r$ " (Lipsey $\&$ Wilson, 2001). For each variable, statistics calculated included mean effect size, observed and corrected/true $S D$, and the $Q$ statistic. In addition, both confidence intervals and credibility intervals were computed (Hunter \& Schmidt, 1990).

\section{Moderator Analyses}

Before proceeding with the moderator analysis, we computed the $Q$ statistic for homogeneity: $Q$ total $\left(Q_{T}\right)$, which tests the null hypothesis that sampling error accounts for observed differences among effect sizes. After grouping the studies on the basis of a shared moderator (e.g., scale version, geographical location, etc.), the homogeneity of the effect sizes was tested by $Q$ within $\left(Q_{W}\right)$, which has an approximate $\chi^{2}$ distribution with $k-1$ degrees of freedom, where $k$ is the number of effect sizes. A significant $Q_{W}$ statistic suggests heterogeneity within a set of studies and the need for further moderator analyses (Cooper \& Hedges, 1994). If the summary analysis of the effect sizes indicated heterogeneity, we computed $Q$ between $\left(Q_{B}\right)$, which has an approximate $\chi^{2}$ distribution with $j-1$ degrees of freedom, where $j$ is number of categories within each moderator variables. A significant $Q_{B}$ indicates that the magnitude of the effect differs between different categories of the moderator.

\section{Results}

The meta-analytic results for the relations between perceptions of organisational politics and its proposed moderators and outcomes are presented in Tables 2 through 4 . For each relation, we report the number of studies included in the analysis of that relation $(k)$, total sample size cumulated across those studies $(N)$, mean corrected correlation ( $\rho$ ), average effect size (Mean ES), uncorrected $S D, S D$ of corrected correlations $\left(S D_{c}\right), 95 \%$ confidence interval (CI), 95\% credibility interval $(\mathrm{CrI}), Q$ total $\left(Q_{T}\right), Q$ within $\left(Q_{W}\right)$, and $Q$ between $\left(Q_{B}\right)$.

In our narrative presentation of the results, we refer only to the significant relations between POP and the variables in our model. Complete information on all relations is provided in Tables 2,3, and 4 .

\section{Consequences of POP}

The results related to the attitudinal consequences of POP are presented in Table 2. As shown, all proposed attitudinal consequences were negatively associated with POP, including, in descending order of magnitude, organisational trust $(d=-0.85)$, followed by interactional justice $(d=-0.82)$, procedural justice $(d=-0.75)$, organisational support $(d=-0.73)$, job satisfaction $(d=-0.54)$, organisational commitment $(d=-0.45)$, distributive justice $(d=-0.41)$, perceived work control $(d=-0.39)$, continuance commitment $(d=-0.28)$, and finally job involvement $(d=-0.27)$.

For the psychological health consequences of POP, both stress $(d=0.44)$ and burnout $(d=0.36)$ showed positive effect sizes (Table 3). Finally, with respect to relations between POP and behavioural consequences (Table 4), job performance, both self and supervisor rated, were negatively related to POP $(d \mathrm{~s}=-0.11$ and -0.16 , respectively). Further analysis of rating source as a 


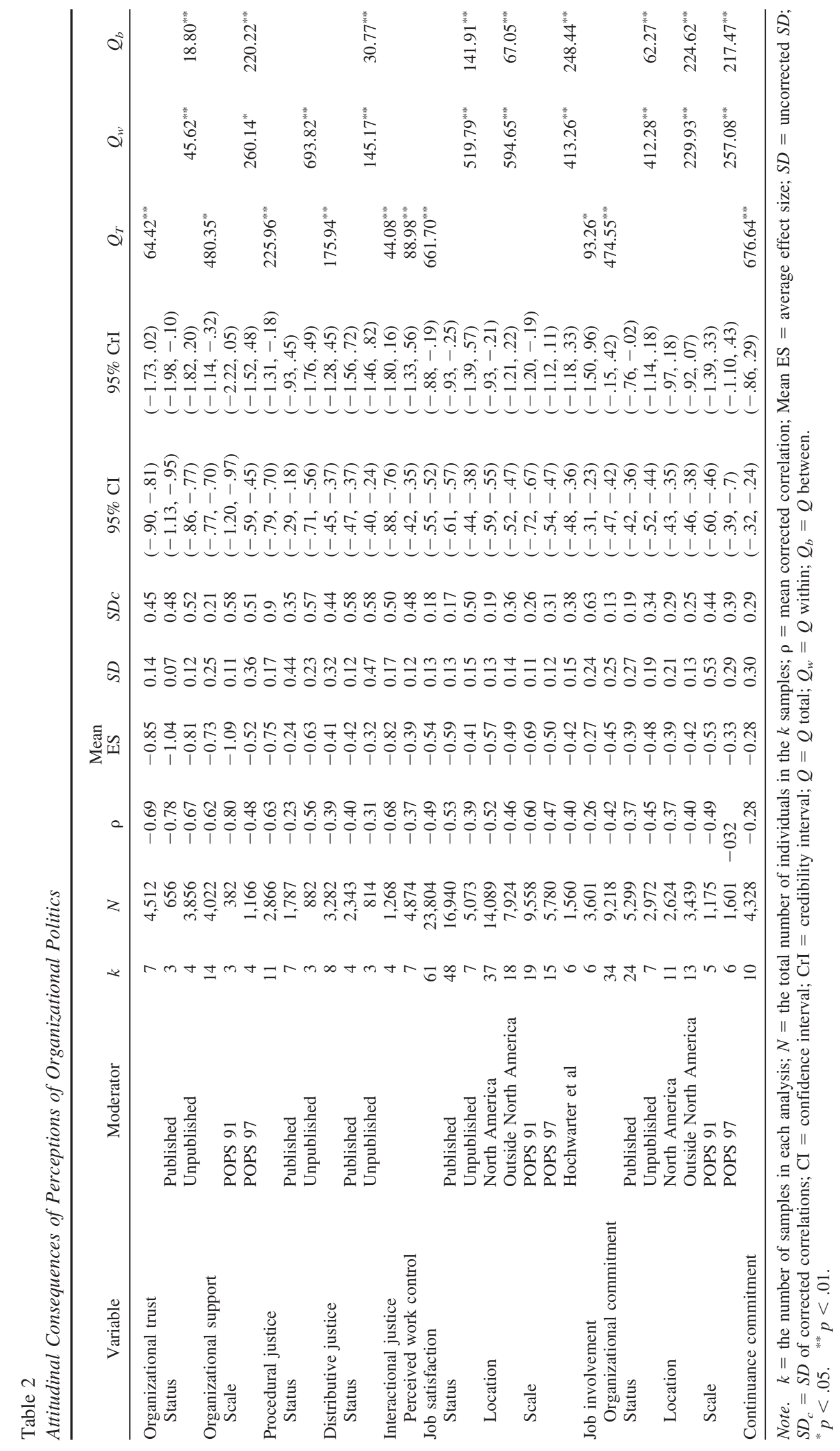


Table 3

Psychological Health Consequences Perceptions of Organizational Politics

\begin{tabular}{|c|c|c|c|c|c|c|c|c|c|c|c|c|}
\hline Variable & Moderator & $k$ & $N$ & $\rho$ & Mean ES & $S D$ & $S D c$ & $95 \% \mathrm{CI}$ & $95 \% \mathrm{CrI}$ & $Q_{T}$ & $Q_{w}$ & $Q_{b}$ \\
\hline Job stress & & 28 & 9,617 & 0.41 & 0.44 & 0.14 & 0.22 & $(.41, .46)$ & $(-.01, .86)$ & $227.05^{* * *}$ & & \\
\hline \multirow[t]{2}{*}{ Location } & North America & 15 & 6,598 & 0.45 & 0.48 & 0.15 & 0.30 & $(.45, .51)$ & $(-.11,1.07)$ & & & \\
\hline & Outside North America & 9 & 2,048 & 0.44 & 0.47 & 0.11 & 0.30 & $(.42, .53)$ & $(-.12,1.07)$ & & $127.07^{\text {*** }}$ & $98.98^{* * *}$ \\
\hline \multirow{3}{*}{ Scale } & POPS 91 & 9 & 4,404 & 0.47 & 0.50 & 0.14 & 0.41 & $(.47, .54)$ & $(-.30,1.31)$ & & & \\
\hline & POPS 97 & 7 & 2,233 & 0.46 & 0.50 & 0.11 & 0.37 & $(.45, .55)$ & $(-.22,1.22)$ & & & \\
\hline & Hochwarter et al. & 3 & 588 & 0.28 & 0.29 & 0.08 & 0.62 & $(.19, .38)$ & $(-.94,1.51)$ & & $87.51^{* * *}$ & $139.54^{* * *}$ \\
\hline Burnout & & 7 & 1,973 & 0.35 & 0.36 & 0.08 & 0.36 & $(.31, .42)$ & $(-.34,1.07)$ & $15.78^{*}$ & & \\
\hline
\end{tabular}

Note. $\quad k=$ the number of samples in each analysis; $N=$ the total number of individuals in the $k$ samples; $\rho=$ mean corrected correlation; Mean ES $=$ average effect size; $S D=$ uncorrected $S D ; S D_{c}=S D$ of corrected correlations; CI = confidence interval; CrI $=$ credibility interval; $Q=Q$ total; $Q_{w}=$ $Q$ within; and $Q_{b}=Q$ between

${ }^{*} p<.05$. *** $p<.01$.

moderator of POP-performance relationship yielded nonsignificant results. Organisational citizenship behaviours $(d=-0.23)$ measured at both the individual and organisational level also demonstrated negative relations $(d \mathrm{~s}=-0.30$ and -0.16 , respectively). POP was positively related to turnover intentions $(d=$ $0.54)$, counterproductive work behaviours $(d=0.45)$, and absenteeism $(d=0.14)$.

For all variables except self-rated performance and absenteeism, the $Q$ statistic, $Q_{T}$, was significant suggesting homogeneity and the presence of moderators for these variables. In the following section, we report on the results of our tests for the existence of moderators.

\section{Potential Moderators}

\section{Publication Bias}

Data on publication bias were available for 12 different variables and in 9 of the 12 comparisons publication bias emerged as a significant moderator. Organisational trust, distributive justice, job satisfaction, job performance (supervisor rated), organisational citizenship behaviours (OCBs), organisational citizenship behaviours-individual (OCB-I), organisational citizenship behaviours-organisational (OCB-O), and counterproductive work behaviours showed stronger effect sizes for published research $(d \mathrm{~s}=-1.04,-0.42,-0.59$, $-0.22,-0.31,-0.36,-0.19$, and 0.55 , respectively) than for unpublished research $(d \mathrm{~s}=-0.81,-0.32,-0.41,-0.44,-0.10$, $-0.17,-0.10,-0.11$, and 0.34 , respectively). However, procedural justice, organisational commitment, and turnover intentions reported stronger effect sizes for unpublished research $(d \mathrm{~s}=$ $-0.63-0.48$, and 0.58 , respectively) than published research $(d \mathrm{~s}=-0.24,-0.39$, and 0.50 , respectively).

\section{Geographical Location}

Data were available for 10 comparisons, and in 8 of the 10 comparisons, we found stronger effect sizes for studies conducted in North America than outside North America. Job satisfaction, job performance (supervisor rated), OCB, OCB-I, absenteeism, and job stress had higher relations with POP in studies conducted in North America $(d \mathrm{~s}=-0.57,-0.21,-0.33,-0.30,0.14$ and 0.48 , respectively) than those conducted outside of North America ( $d \mathrm{~s}=$ $-0.49,-0.12,-0.16,-0.22,0.13$, and 0.47 , respectively). How- ever, relations with organisational commitment, counterproductive work behaviours, and turnover intentions were stronger in nonNorth American studies ( $d \mathrm{~s}=-0.42,0.55$, and 0.60 , respectively) than in North American studies $(d \mathrm{~s}=-0.39,0.34$, and 0.47 , respectively).

\section{Measurement of POP}

Finally, with respect to the measurement of POP, where data were available, we compared effect sizes for POPS 91 and POPS 97 scales with Hochwarter et al.'s (2003) scale. In 11 of the 12 comparisons, the differences in the mean effect sizes between the groups were significant. Specifically, the results were: organisational support $(d=-1.09$ for POPS 1991 and $d=-0.52$ for POPS 1997), organisational commitment $(d=-0.53$ for POPS 1991 and $d=-.33$ for POPS 1997), job performance (supervisor rated; $d=-0.31$ for POPS 1991 vs. $d=-0.21$ for Hochwarter et al. [2003]), OCB ( $d=-0.37$ for POPS 1991 and $d=-0.30$ for POPS 1997), OCB-I ( $d=-0.15$ for POPS 1991 and $d=-0.35$ for POPS 1997), job satisfaction ( $d=-0.69$ for POPS 1991, $d=$ -0.50 for POPS 1997 vs. $d=-0.42$ for Hochwarter et al., 2003), turnover intentions $(d=0.52$ for POPS 1991 and $d=0.47$ for POPS 1997), and job stress ( $d=0.50$ for POPS 1991 and $d=0.50$ for POPS 1997 vs. $d=0.29$ for Hochwarter et al., 2003).

\section{Discussion}

The results of this meta-analysis contribute to the theory and research on perceptions of organisational politics and its proposed consequences (Ferris et al., 2002; 1989). The results show that POP is associated with a range of attitudinal, health-related, and behavioural criteria that reflect harmful consequences of experiencing politics at work. In this way, our results are consistent with the results of previous meta-analyses (Chang et al., 2009; Miller et al., 2008). However, the magnitudes of some relations differ from the previous meta-analyses. For example, with respect to POP's relation with job satisfaction, we found mean corrected correlation of -.49 , compared with -.57 for Chang et al. (2009) and -.45 for Miller et al. (2008). Such differences may be because of the larger number of studies, samples, and participants in the present study, which should render the estimates more stable.

In addition, the moderator analyses demonstrate that some methodological features may influence the observed relations with 


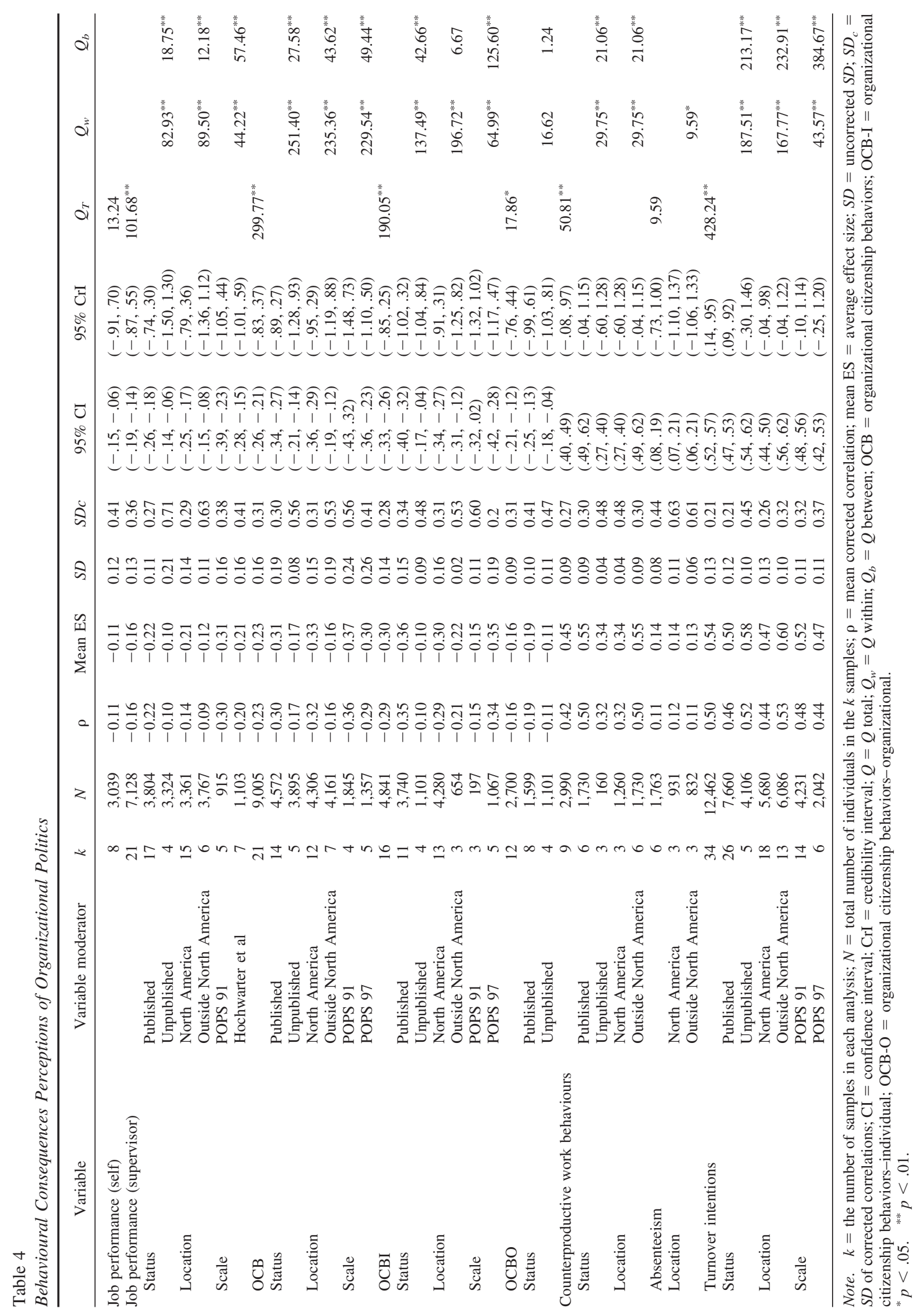


POP. These results suggest that where a study is conducted, the version of the POP scale used, and the study's publication status may have nontrivial effects on relations with POP and need to be considered and, if possible, accounted for when designing and interpreting the results of individual studies. Below, we elaborate on these contributions and their implications for theory on POP and offer numerous suggestions for future research.

\section{Consequences of POP}

Regarding the proposed attitudinal consequences of POP, we found that both job satisfaction and indicators of organisational commitment were negatively associated with POP, supporting the notion that exposure to POP at work can undermine these work attitudes. It is important to recognise however, that although the vast majority of POP literature has positioned satisfaction and commitment as consequences of POP, this is not the only direction these relations can take. A longitudinal study conducted by Vigoda and Cohen (2002) provided evidence that job satisfaction and organisational commitment negatively predicted POP, suggesting that those with negative work attitudes may be more likely to experience or perceive POP. Thus, while our results substantiate negative relations between these work attitudes and POP, further research is needed to explore how they may shape and be shaped by POP.

Regarding the justice dimensions, POP exhibited negative relations, in decreasing order of magnitude, with interactional $(d=$ $-.82)$, procedural $(d=-.75)$, and distributive $(d=-.41)$ justice. The magnitudes of the relations suggest that employees in work environments that are characterised by politics are more likely to perceive injustice. The stronger effect sizes for interactional and procedural justice compared with distributive justice suggest that POP is more strongly associated with perceptions of unfair interpersonal treatment perceptions of unfair organisational decisionmaking than perceptions of unfair of allocation of resources. The association with unfair interpersonal treatment is related to political work environments being characterised by various forms of incivility and mistreatment, likely because of employees pursuing and protecting their own interests at the expense of others. The association with procedural unfairness is tied to the favoritism, opportunism, and general lack of decision-making transparency that define political work environments.

In a related finding, POP also exhibited a strong negative relation with organisational trust $(d=-.85)$, demonstrating that where politics are present, trust likely is not. What is unclear from these data and previous research, however, is the direction of this relation. We suggest that the relation is likely reciprocal. In one direction, the presence of POP would erode one's trust in the organisation and one's coworkers, and in the other direction, feelings of mistrust would lead to increased perceptions of politics. Thus, it is likely that feelings of mistrust and perceptions of politics mutually reinforce each other, although research is needed to investigate this suggestion. The magnitude of the POP-trust relation suggests that the presence of POP virtually guarantees that mistrust will also be present, but it also raises questions about the uniqueness of the two constructs and suggests the need for further research examining the discriminant validity of their measures as has been done previously with POP, organisational support, and perceptions of organisational justice (Andrews \& Kacmar, 2001).
Our results also substantiated that POP is positively associated with perceived stress and burnout, supporting its positioning as a demand according to JD-R theory. Working in a politicized work environment is a stressor that compromises employees' psychological health, manifesting in higher levels of stress and symptoms of burnout. These relations with stress and burnout also likely explain, at least in part, why POP also predicts negative behavioural criteria.

In this vein, POP was found to be positively related to counterproductive work behaviours (CWB), and negatively related to organisational citizenship behaviours (OCB) and job performance. In most of the studies that included CWB, CWB was primarily operationalized as behaviours that reflect passive withdrawal from one's work (e.g., arriving late, taking extended breaks, etc.) suggesting that those who experience politics may respond by engaging in such forms of withdrawal. Comparatively less research has examined whether POP may predict other, more active forms of counterproductive behaviour, such as aggression, theft, or physical threats or assaults. As a result, no conclusions can be drawn about POP and these forms of CWB. Job performance exhibited a negative relation with perceptions of organisational politics, with similar effect sizes being observed for both supervisor-rated and self-rated measures of performance. POP predicted both absenteeism and turnover intentions, although its relation to turnover intentions was stronger.

Most of the effect sizes observed in this study were consistent with, although larger in magnitude than, those found in the previous reviews by Chang et al. (2009) and Miller et al. (2008) demonstrating that increased perceptions of organisational politics are associated with a wide range of detrimental consequences for individual employees (e.g., lower job satisfaction, job performance, OCBs, and organisational commitment, and increased stress and turnover intentions), substantiating the classification of POP as a job demand or stressor (e.g., Demerouti et al., 2001; Schaufeli \& Bakker, 2004). Future research on POP could benefit from the use of the JD-R model or other theories in order to strengthen the theoretical foundations of POP research and to guide interventions that may help to its prevention and amelioration of its negative effects.

Although our focus was primarily on presenting POP as a job demand that is associated with a wide range of negative criteria, it is important to realise that some scholars have suggested that this is because existing measures of politics are skewed toward measuring negative political behaviours and perceptions (e.g., Fedor \& Maslyn, 2002; Ferris et al., 2002). Thus, POP may also act as a resource and include more positive behaviours and may have both negative and positive consequences-perhaps for different people or groups. To effectively investigate POP as a resource and its potential positive outcomes, it may be necessary to expand the construct definition of organisational politics and to use a modified measure that more fully captures other forms of political behaviour (see Fedor \& Maslyn, 2002). We encourage more research examining other, potentially positive consequences of POP, and conditions under which these they may emerge. For example, research is needed to investigate whether those who experience positive consequences of politics do so at the expense of others. Such findings would, of course, raise the ethical question of whether such consequences are appropriately defined as "positive" even if they are assessed as 
such by their beneficiaries. In other cases, political behaviour may be engaged in by some as a means of addressing an injustice being perpetrated by those with organisational power and authority who may perceive such behaviour as negative because it threatens their power, even though their power may have been unjustly obtained or used. In such cases, political behaviour may be "positive" in the sense of having honourable, rather than self-interested, intentions, in ways that are akin to the notion of positive deviance (Spreitzer \& Sonenshein, 2004). In light of this, research that more specifically regards the perspective of the "perceiver" of politics, and what they stand to lose or gain as a result of political behaviour, would make important theoretical contributions to the literature on organisational politics.

\section{Moderators of Relations Involving POP}

We investigated the importance of three moderators in this study: publication status, geographic origin of data, and version of POP measure used. For some variables in the model, insufficient data precluded moderator analysis, so it is important to realise that there are relations that may be moderated, but that we were not able to test. Below, we discuss the nature and implications of a number of the moderation effects we observed.

\section{POP and the File Drawer Problem}

One of the strengths of this study was the inclusion of a large number of unpublished studies $(k=18)$. For most variables where there were sufficient data to examine this moderator, we found partial evidence that effect sizes for published studies were larger than those for unpublished studies. These results are in agreement with the previous meta-analytic study by Chang et al. (2009) which found little evidence for publication bias. However, the magnitude of the effect sizes reported in this study was different than those reported by Chang et al. (2009). For instance, with respect to job satisfaction, our results indicated stronger effect size for published studies -.53 versus -.39 for unpublished studies, while Chang et al. (2009) reported stronger effect size for unpublished studies -.61 versus -.57 for published research. Of course, smaller effect sizes in unpublished research could represent results that are truly nonsignificant (or significant but of negligible magnitude), but could also represent results that are nonsignificant because of methodological or other shortcomings, which could both attenuate effect sizes and reduce its likelihood of publication. Regardless, researchers need to be aware that we observed variance in effect sizes between published and unpublished research.

\section{Importance of Geographic Context}

Much of what is theorized and known about POP comes from North American data. Recently, scholars have called for crosscultural research on POP (e.g., Harris \& Kacmar, 2005b), suggesting that some cultural characteristics may influence POP and its relations with other variables. In this meta-analysis, we conducted a preliminary, and admittedly rather coarse, test of this by examining whether geographic origin of the data moderates relations involving POP. In our meta-analysis, we found that 8 of 10 criteria exhibited stronger relations with POP in studies conducted in
North America than those conducted elsewhere. For example, POP was more strongly associated with stress and dissatisfaction for North American than non-North American employees. Similarly, the negative relation between POP and supervisory ratings of job performance was stronger in North America than elsewhere. These results complement the results of Chang et al. (2009) who found that POP had stronger effects on the morale of U.S. employees compared with their Israeli counterparts who may have greater tolerance for political activities or may consider politics as normative and morally legitimate. The pattern was reversed for two variables, however, with the positive relations between POP and turnover intentions and with CWB being stronger in studies conducted outside North America.

We recognise that a number of explanations could be offered for the cultural/geographic differences were observed. For now, we suggest that two cultural characteristics may, in part, explain the results we observed: individualism and power distance (Hofstede, 1980). In the meta-analytic database, most of the data from outside of North America came from India, China, and Israel, cultures that tend to be higher in power distance and lower in individualism than North America. Employees from cultures that are higher in power distance may consider political behaviours-particularly by those with higher status - to be more normal or acceptable and, therefore, less likely to evoke negative reactions such as stress or dissatisfaction. Individualism-collectivism may also influence employee reactions to POP. Employees in more individualistic (less collectivistic) cultures may be more sensitive to self-interested behaviour-or may view it as less legitimate-and react more negatively to it (Romm \& Drory, 1988). The two exceptionsturnover intentions and CWB (which reflect withdrawal behaviours) — suggest that passive withdrawal behaviours (e.g., thinking about quitting one's job) are one set of criteria that are more likely to be associated with POP in non-North American countries. Although our categorisation was somewhat coarse, these results do suggest the presence of cross-cultural variation in relations with POP and the need for more theoretical development and research to understand the nature of this variation.

\section{Implications for the Measurement of POP}

With respect to the scale type, there was some evidence that the two primary measures of POP exhibited differential relations with several criteria. For example, POPS 91 showed stronger effect sizes than POPS 97 for job satisfaction, turnover intentions, organisational support, and organisational commitment, whereas the opposite was true for job stress and OCB. For the few comparisons for which we had sufficient data to include the Hochwarter et al. (2003) measure, it exhibited relations that were somewhat smaller in magnitude than POPS 91 and POPS 97. Although there is content overlap between POPS 97 and POPS 91, compared with POPS 97, POPS 91 contains more items measuring general political behaviour (GPB), which includes behaviour of individuals who act in self serving manner to obtain valued outcomes; and fewer items measuring the other two dimensions: going along to get ahead (GATGA), which describes behaviours that constitute a lack of action by individuals (e.g., remain silent); and "pay and promotions policies" (PPP), where organisational policies reward and perpetuate political behaviours. Perhaps the variation in content between the two measures explains the variation in their 
relative relations with these variables. It may be, for example, that the GPB items unique to POPS 91 are more strongly associated with work attitudes (i.e., job satisfaction and organisational commitment) whereas the GATGA and PPP items from POPS 97 are more strongly related to stress and behavioural outcomes such as OCB. Given this possibility, there may be merit in investigating whether the different POPS dimensions are differentially related to the consequences that have been observed for the overall POP construct. Such research would help to advance POP theory by clarifying whether there are unique dimensions of POP that are responsible for certain relations that are currently attributed to POP in general, or whether there are certain unique relations that may exist but be "washed out" when an overall measure of POP is used (e.g., Zhou \& Ferris, 1995). Whatever the explanation, researchers should be aware that although POPS 91 and POPS 97 contain overlapping content and generally exhibit consistent relations with other variables, they are not necessarily equivalent.

\section{Limitations}

It is important to note several limitations of the current metaanalysis. First, many of the relations estimated in this metaanalysis involve a small number of studies; hence, it should be recognised that second-order sampling error poses a threat to the validity of our reported results (Hunter \& Schmidt, 1990). Second, we were unable to search for moderators for some relations in our model because sufficient data were unavailable. Although this limitation is common in meta-analytic research (e.g., Rhoades \& Eisenberger, 2002; Willness, Steel, \& Lee, 2007), the variability in effect sizes suggested the presence of moderators for a number of relations with POP (e.g., burnout, procedural justice) that we were unable to investigate. Third, because of insufficient data, we were only able to estimate the relations between overall POP and the variables in the model and were unable to estimate the relations involving the three POP dimensions. Although research shows that these dimensions are intercorrelated, they nevertheless reflect unique aspects of POP that may exhibit different relations with variables in the model. Fourth, the cross-sectional nature of most studies of organisational politics precludes making causal inferences, even though the theoretical model on which our metaanalysis was based (Ferris et al., 2002; 1989) implies directional relations. We echo the call of many organisational politics researchers regarding the need for longitudinal research designs to better address the causal nature of relations involving perceptions of organisational politics. Finally, although meta-analytically derived effect sizes are often designated as population parameters, it is important to recognise that the observed relations do not represent a defined population, per se. Because they are based on data aggregated from a large number of samples, meta-analytic results are more dependable than relations based on smaller, narrower samples, but they are not true population parameters and should not be interpreted as such.

\section{Practical Implications}

Many of the potential practical implications that can be derived from our results have already been discussed by authors of the primary studies that comprise our meta-analysis. However, we do believe it is appropriate to briefly highlight a more general prac- tical implication that relates to the pattern of relations we observed between POP and its proposed consequences. Specifically, the relations that exist between $\mathrm{POP}$ and a wide range of negative attitudinal, health-related, and behavioural variables suggest that POP has potentially significant direct and indirect costs for individuals and organisations related to compromised trust, feelings of injustice, negative worker attitudes, undermined performance and productivity and costs related to turnover and absence. The indirect financial costs of these effects have not been measured to our knowledge, but aggregated across thousands of organisations, these costs would likely be significant. Accordingly, these results should be taken as a call to organisations to give more attention to the prevention and effective management of political behaviour. Prevention efforts may include steps to reduce ambiguity in the work environment and to ensure that policies related to pay and promotion as well as other managerial decisions are clearly communicated and fairly executed. It is also incumbent on managers in organisations to monitor the social and behavioural dynamics in their organisations and to intervene when they observe unhealthy patterns of behaviour. With respect to more effective management of political behaviour, research showing the benefits of individual political skill (e.g., Kolodinsky, Hochwarter, \& Ferris, 2004) suggests that efforts to develop political and other interpersonal skills (through training, e.g.) may help individuals to function more effectively and be less negatively affected by political behaviour in their work environment.

\section{Conclusion}

This study represents a meta-analytic review of the previous research examining the attitudinal, psychological health, and behavioural consequences of perceptions of organisational politics. Moreover, the moderator analyses shed light on a number of characteristics that influence the magnitude and direction of the relations between politics and other variables. These results have implications for interpreting the results of previous research and for future research on organisational politics.

\section{Résumé}

Dans cette étude, nous rapportons les résultats d'une méta-analyse des relations entre les perceptions des politiques organisationnelles (PPO) et les variables dans les attitudes, la santé psychologique et le comportement, selon les données de 118 échantillons indépendants regroupant au total 44560 participants. Parmi les variables examinées, les PPO étaient les plus étroitement associées à la confiance dans les institutions et la justice interactionnelle, tout en présentant des liens positifs avec divers autres critères, dont les relations positives avec le stress, l'épuisement professionnel, les intentions de départ et les comportements improductifs au travail, ainsi que des liens négatifs avec la satisfaction au travail, le comportement du citoyen et le rendement au travail. Nous avons aussi constaté que l'ampleur de l'effet était parfois atténuée par le statut de publication, l'origine géographique des données et les types de mesures utilisés pour évaluer les PPO.

Mots-clés : perceptions des politiques organisationnelles, stress, satisfaction au travail, absentéisme, confiance dans l'institution. 


\section{References}

References marked with an asterisk indicate studies included in the meta-analysis.

*Abbas, M., \& Raja, U. (2010, August). Combined effects of perceived organizational politics and psychological capital on job outcomes. Paper presented at the Academy of Management conference, Montreal, Canada.

*Albrecht, S. (2006a). The direct and indirect influence of organizational politics on organizational support, trust, and commitment. In E. Vigoda Gadot \& A. Drory (Ed.), Handbook of organizational politics (pp. 107-121). Cheltenham, UK: Edward Elgar Publishing House.

*Albrecht, S. (2006b). Organizational politics: Affective reactions, cognitive assessments and their influence on organizational commitment and cynicism toward change. In E. Vigoda Gadot \& A. Drory (Ed.), Handbook of organizational politics (pp. 230-252). Cheltenham, UK: Edward Elgar Publishing House.

*Andrews, M. C., \& Kacmar, K. M. (2001). Discriminating among organizational politics, justice, and support. Journal of Organizational Behavior, 22, 347-366. doi:10.1002/job.92

"Andrews, M. C., Witt, L. A., \& Kacmar, K. M. (2003). The interactive effects of organizational politics and exchange ideology on manager ratings of retention. Journal of Vocational Behavior, 62, 357-369. doi:10.1016/S0001-8791(02)00014-3

*Aryee, S., Chen, Z. X., \& Budhwar, P. S. (2004). Exchange fairness and employee performance: An examination of the relationship between organizational politics and procedural justice. Organizational Behavior and Human Decision Processes, 94, 1-14. doi:10.1016/j.obhdp.2004.03 .002

Atinc, G., Darrat, M., Fuller, B., \& Parker, B. (2010). Perceptions of organizational politics: A meta-analysis of theoretical antecedents. Journal of Managerial Issues, 22, 494-513.

Bakker, A. B., \& Demerouti, E. (2007). The job demands-resources model: State of the art. Journal of Managerial Psychology, 22, 309-328. doi:10.1108/02683940710733115

Bakker, A. B., Demerouti, E., \& Verbeke, W. (2004). Using the job demands-resources model to predict burnout and performance. Human Resource Management, 43, 83-104. doi:10.1002/hrm.20004

*Bouckenooghe, D., \& Menguç, B. (2010, May). Organizational politics and the moderating role of organizational climate on change recipients' readiness for change. Paper presented at the Administrative Sciences Association of Canada, Regina.

*Bozeman, D. P., Hochwarter, W. A., Perrewe, P. L., \& Brymer, R. A. (2001). Organizational politics, perceived control, and work outcomes: Boundary conditions of the effects of politics. Journal of Applied Social Psychology, 31, 486-503. doi:10.1111/j.1559-1816.2001.tb02052.x

*Breaux, D. M., Munyon, T. P., Hochwarter, W. A., \& Ferris, G. R. (2009). Politics as the moderator of accountability job satisfaction relationship: Evidence across three studies. Journal of Management, 35, 307-326. doi: $10.1177 / 0149206308318621$

*Brouer, R. L., Ferris, G. R., Hochwarter, W. A., Laird, M. D., \& Gilmore, D. C. (2006). The strain related reactions to perceptions of organizational politics as a workplace stressor: Political skill as neutralizer. In E. Vigoda Gadot \& A. Drory (Ed.), Handbook of organizational politics (pp. 187-208). Cheltenham, UK: Edward Elgar Publishing House.

*Brouer, R. L., Harris, K. J., \& Kacmar, K. M. (2011). The moderating effects of political skill on perceived politics-outcome relationships. Journal of Organizational Behaviour, 32, 869-885. doi:10.1002/job .718

*Chang, C. H., Rosen, C. C., \& Levy, P. E. (2009). The relationship between perceptions of organizational politics and employee attitudes, strain, and behaviour: A meta-analytic examination. Academy of Management Journal, 52, 779-801. doi:10.5465/AMJ.2009.43670894
*Chivakidakarn, Y. (2000). Perceptions of organizational politics: A comparison of local Thai companies and multinational corporations in Thailand. Unpublished doctoral dissertation, Nova Southeastern University.

${ }^{*}$ Connor, W. E. (1998). Application of social role theory to the phenomena of perceived and self reported use of organizational political behaviour. Unpublished doctoral dissertation, Carleton University.

Cooper, H., \& Hedges, L. V. (1994). The handbook of research synthesis. New York, NY: Russel Sage Foundation.

${ }^{*}$ Cropanzano, R., Howes, J. C., Grandey, A. A., \& Toth, P. (1997). The relationship of organizational politics and support to work behaviours, attitudes, and stress. Journal of Organizational Behavior, 18, 159-180. doi:10.1002/(SICI)1099-1379(199703)18:2<159::AID-JOB795>3.0 .CO;2-D

"Danaeefard, H., Balutbazeh, A. E., \& Kashi, K. H. (2010). Good soldiers perceptions of organizational politics. Understanding the relation between organizational citizenship behaviours and perceptions of organizational politics: Evidence from Iran. European Journal of Economics, Finance, and Administrative Sciences, 18, 146-162.

*Darr, W., \& Johns, G. (2004). Political decision-making climates: Theoretical processes and multi-level antecedents. Human Relations, 57, 169-200. doi:10.1177/0018726704042926

Deci, E. L., \& Ryan, R. M. (1985). Intrinsic motivation and selfdetermination in human behavior. New York, NY: Plenum Press. doi: 10.1007/978-1-4899-2271-7

Demerouti, E., Bakker, A. B., Nachreiner, F., \& Schaufeli, W. B. (2001). The job demands-resources model of burnout, Journal of Applied Psychology, 86, 499-512. doi:10.1037/0021-9010.86.3.499

*Doucet, O., Lapalme, M. E., \& Simard, G. (2009, August). Leader and context influences on employees' perceptions of organizational politics. Paper presented at the Academy of Management Conference, Chicago.

*Drory, A. (1993). Perceived political climate and job attitudes. Organization Studies, 14, 59-71. doi:10.1177/017084069301400105

*Eisenberg, A. (1999). The search for integrity: A leadership impact study. Unpublished doctoral dissertation, DePaul University, Chicago, Illinois.

Erdogan, B., Kraimer, M. L., \& Liden, R. C. (2004). Work value congruence and intrinsic career success: The compensatory roles of leadermember exchange and perceived organizational support, Personnel Psychology, 57, 305-332. doi:10.1111/j.1744-6570.2004.tb02493.x

Fedor, D., \& Maslyn, J. (2002). Politics and political behaviour: Where else do we go from here? In F. Dansereau \& F. J. Yammarino (Eds.), Research in multi-level issues (pp. 271-285). Oxford, United Kingdom: Elsevier Science/JAI Press. doi:10.1016/S1475-9144(02)01036-6

Ferris, G. R., Adams, G., Kolodinsky, R. W., Hochwarter, W. A., \& Ammeter, A. P. (2002). Perceptions of organizational politics: Theory and research directions. In F. J. Yammarino \& F. Dansereau (Ed.), Research in multi-level issues: The many faces of multi level issues (pp. 179-254). Oxford, United Kingdom: JAI Press/Elsevier Science. doi: 10.1016/S1475-9144(02)01034-2

*Ferris, G. R., Brand, J. F., Brand, S., Rowland, K. M., Gilmore, D. C., Kacmar, K. M., \& Burton, C. A. (1993). Politics and control in organizations. In E. J. Lawler, B. Markovsky, K. Heimer, \& J. O’Brien (Eds.), Advances in group processes (Vol. 10, pp. 83-111). Greenwich, CT: JAI Press.

*Ferris, G. R., Frink, D. D., Galang, M. C., Zhou, J., Kacmar, K. M., \& Howard, J. L. (1996). Perceptions of organizational politics: Predictors, stress-related implications, and outcomes. Human Relations, 49, 233 266. doi: $10.1177 / 001872679604900206$

*Ferris, G. R., Frink, D. D., Gilmore, D. C., \& Kacmar, K. M. (1994). Understanding as an antidote for the dysfunctional consequences of organizational politics as a stressor. Journal of Applied Social Psychology, 24, 1204-1220. doi:10.1111/j.1559-1816.1994.tb01551.x

*Ferris, G. R., Harrell-Cook, G., \& Dulebohn, J. H. (2000). Organizational politics: The nature of the relationship between politics perceptions and 
political behavior. In S. B. Bacharach, \& E. J. Lawler (Eds.), Research in the sociology of organizations (Vol. 17, pp. 89-130). Stamford, CT: JAI Press.

Ferris, G. R., \& Kacmar, K. M. (1989, October). Perceptions of organizational politics. Paper presented at the Academy of Management meeting, Washington, DC.

*Ferris, G. R., \& Kacmar, K. M. (1992). Perceptions of organizational politics. Journal of Management, 18, 93-116. doi:10.1177/ 014920639201800107

Ferris, G. R., Russ, G. S., \& Fandt, P. M. (1989). Politics in organizations. In R. A. Giacalone \& P. Rosenfeld (Ed.), Impression management in the organization (pp. 143-170). Hillsdale, NJ: Erlbaum.

Folkman, S., \& Lazarus, R. S. (1985). If it changes it must be a process Study of emotion and coping during three stages of a college examination. Journal of Personality and Social Psychology, 48, 150-170. doi: 10.1037/0022-3514.48.1.150

"Ford, J. M. (2001). Organizational politics and multi source feedback. Unpublished doctoral dissertation, Louisiana State University.

*Gandz, J., \& Murray, V. (1980). The experience of workplace politics. Academy of Management Journal, 23, 237-251. doi:10.2307/255429

*Gibney, R., Zagenczyk, T. J., \& Masters, M. F. (2009). The negative aspects to social exchange: An introduction to perceived organizational obstruction. Group \& Organization Management, 34, 665-697. doi: 10.1177/1059601109350987

*Gilmore, D. C., Ferris, G. R., Dulebohn, J. H., \& Harrell-Cook, G. (1996). Organizational politics and employee attendance. Group \& Organization Management, 21, 481-494. doi:10.1177/1059601196214007

*Halbesleben, J. R. B. (2006). The relationship between perceptions of politics, social support, withdrawal and performance. In E. Vigoda Gadot \& A. Drory (Ed.), Handbook of organizational politics (pp. 253-270). Cheltenham, UK: Edward Elgar Publishing House.

"Harris, K. J. (in press). A test of competing models of the relationship between perceptions of politics, perceived organizational support, and individual outcomes. Journal of Social Psychology.

*Harris, K. J., Harris, R. B., \& Wheeler, A. R. (2005). Relationships between politics, supervisor communication, and job outcomes. Journal of Occupational and Organizational Psychology, 78, 337-354. doi: $10.1348 / 096317905 X 26110$

*Harris, K. J., \& Kacmar, K. M. (2005a). Easing the strain: The buffer role of supervisors in the perceptions of politics-strain relationship. Journal of Applied Social Psychology, 39, 2669-2688. doi:10.1111/j.1559-1816 .2009.00543.x

Harris, K. J., \& Kacmar, K. M. (2005b). Organizational politics. In J. Barling, E. K. Kelloway, \& M. Frone (Eds.), Handbook of work stress (pp. 353-374). Thousand Oaks, CA: Sage Publications. doi:10.4135/ 9781412975995.n14

Hedges, L. V., \& Olkin, I. (1985). Statistical methods for meta-analysis. Orlando, FL: Academic Press.

Hemingway, M., \& Smith, C. S. (1999). Organizational climate and occupational stressors as predictors of withdrawal behaviors and injuries in nurses. Journal of Occupational and Organizational Psychology, 72, 285-299. doi:10.1348/096317999166680

*Hochwarter, W. A. (2003). The interactive effects of pro-political behaviour and politics perceptions on job satisfaction and affective commitment. Journal of Applied Social Psychology, 33, 1360-1378. doi: 10.1111/j.1559-1816.2003.tb01953.x

"Hochwarter, W. A., James, M., Johnson, D., \& Ferris, G. R. (2004). The interactive effects of politics perceptions and trait cynicism on work outcomes. Journal of Leadership \& Organizational Studies, 10, 44-55. doi:10.1177/107179190401000404

Hochwarter, W. A., Kiewitz, C., Castro, S. L., Perrewe, P. L., \& Ferris, G. R. (2003). Positive affectivity and collective efficacy as moderators of the relationship between perceived politics and job satisfaction. Jour- nal of Applied Social Psychology, 33, 1009-1035. doi:10.1111/j.15591816.2003.tb01936.x

*Hochwarter, W. A., Kolodinsky, R. W., Witt, L. A., Hall, A. T., Ferris, G. R., \& Kacmar, M. K. (2006). Competing perspectives in the role of understanding in the politics perceptions-job performance relationship: A test of the "antidote" versus "distraction" hypotheses. In E. Vigoda Gadot \& A. Drory (Eds.), Handbook of organizational politics (pp. 271-285). Cheltenham, UK: Edward Elgar Publishing House.

*Hochwarter, W. A., Perrewe, P. L., Ferris, G. R., \& Guercio, R. (1999). Commitment as an antidote to the tension and turnover consequences of organizational politics. Journal of Vocational Behavior, 55, 277-297. doi:10.1006/jvbe. 1999.1684

*Hochwarter, W. A., \& Thompson, K. R. (2010). The moderating role of optimism on politics-outcomes relationships: A test of competing perspectives. Human Relations, 63, 1371-1394. doi:10.1177/ 0018726709357250

*Hochwarter, W. A., \& Treadway, D. C. (2003). The interactive effects of negative and positive affect on the politics perceptions-job satisfaction relationship. Journal of Management, 29, 551-567.

*Hochwarter, W. A., Witt, L. A., \& Kacmar, K. M. (2000). Perceptions of organizational politics as a moderator of the relationship between conscientiousness and job performance. Journal of Applied Psychology, 85, 472-478. doi:10.1037/0021-9010.85.3.472

Hofstede, G. (1980). Culture's consequences: International differences in work-related values. Beverly Hills, CA: Sage.

*Howell, S. K. (2005). Adaptive self-regulation and organizational politics: Investigating the effects in the accounting profession. Unpublished doctoral dissertation, University of Central Florida.

"Hsiung, H. H., Lin, C. W., \& Lin, C. S. (2012). Nourishing or suppressing? The contradictory influences of perception of organizational politics on organizational citizenship behaviour. Journal of Occupational and Organizational Psychology, 85, 258-276. doi:10.1111/j.2044-8325 2011.02030.x

"Huang, I. C., Chuang, C. J., \& Lin, H. C. (2003). The role of burnout in the relationship between perceptions of organizational politics and turnover intentions. Public Personnel Management, 32, 519-531.

Hunter, J. E., \& Schmidt, F. L. (1990). Methods of meta-analysis: Correcting error and bias in research findings. Newbury Park, CA: Sage.

*Innes, P. B. (2004). The influence of leadership on perceptions of organizational politics, job involvement, and organizational commitment. Unpublished doctoral dissertation, Regent University.

"Jam, F. A., Sheikh, R. A., Iqbal, H., Zaidi, B. H., Yasir, A., \& Muzaffar M. (2011). Combined effects of perception of politics and political skill on employee job outcomes. African Journal of Business Management, 5 , 9896-9904.

*James, M. (2005). Antecedents and consequences of cynicism in organizations: An examination of the potential positive and negative effects on school systems. Unpublished doctoral dissertation, Florida State University.

*James, M., Treadway, D. C., Conner, D., \& Hochwarter, W. A. (2005). The interactive effects of positive affect and a sense of competency on the politics perceptions-job satisfaction relationship. Journal of Applied Social Psychology, 35, 798-820. doi:10.1111/j.1559-1816.2005 tb02147.x

*Joseph, B. (2006). Affective, continuance, and normative commitment among student affairs professionals. Unpublished doctoral dissertation, North Carolina State University.

*Jun, L., Xiaoyu, L., \& Xiaobo, T. (2010). Two side charismatic leadership, organizational politics perception, and employee innovation: A mediation model. Advanced Management Science, 1, 625-629.

*Kacmar, K. M., Bachrach, D. G., Harris, K. J., \& Zivnuska, S. (2011). Fostering good citizenship through ethical leadership: Exploring the moderating role of gender and organizational politics. Journal of Applied Psychology, 96, 633-642. doi:10.1037/a0021872 
*Kacmar, K. M., Bozeman, D. P., Carlson, D. S., \& Anthony, W. P. (1999). An examination of the perceptions of organizational politics model: Replication and extension. Human Relations, 52, 383-416. doi:10.1177/ 001872679905200305

Kacmar, K. M., \& Carlson, D. (1997). Further validation of the Perceptions of Politics Scale (POPS): A multiple sample investigation. Journal of Management, 23, 627-658. doi:10.1177/014920639702300502

"Kacmar, K. M., Collins, B. J., Harris, K. J., \& Judge, T. A. (2009). Core self evaluations and job performance: The role of the perceived work environment. Journal of Applied Psychology, 94, 1572-1580. doi: 10.1037/a0017498

Kacmar, K. M., \& Ferris, G. R. (1991). Perceptions of Organizational Politics Scale (POPS): Development and construct validation. Educational and Psychological Measurement, 51, 193-205. doi:10.1177/ 0013164491511019

*Kiewitz, C., Ferris, G. R., Hochwarter, W. A., \& Castro, S. L. (2002). The role of psychological climate in neutralizing the effects of organizational politics on work outcomes. Journal of Applied Social Psychology, 32, 1189-1207. doi:10.1111/j.1559-1816.2002.tb01431.x

*Kiewitz, C., Restubog, S. L., Zagenczyk, T., \& Hochwarter, W. (2009). The interactive effects of psychological contract breach and organizational politics on perceived organizational support: Evidence from two longitudinal studies. Journal of Management Studies, 46, 806-834. doi:10.1111/j.1467-6486.2008.00816.x

Kolodinsky, P., Hochwarter, W. A., \& Ferris, G. R. (2004). Nonlinearity in the relationship between political skill and work outcomes: Convergent evidence from three studies. Journal of Vocational Behavior, 65, 294308. doi:10.1016/j.jvb.2003.08.002

Kozlowski, S. W. J., \& Doherty, M. L. (1989). Integration of climate and leadership: Examination of a neglected issue. Journal of Applied Psychology, 74, 546-553. doi:10.1037/0021-9010.74.4.546

"LaCost, H. A. (2005). Attributions of organizational politics: An investigation of locus of causality, justice and intentionality as factors in perceptions of politics. Unpublished doctoral dissertation, Northern Illinois University.

*Ladebo, O. J. (2006). Perceptions of organizational politics: Examination of a situational antecedent and consequences among Nigeria's extension personnel. Applied Psychology: An International Review, 55, 255-281. doi:10.1111/j.1464-0597.2006.00230.x

Lepine, J. A., Podsakoff, N. P., \& LePine, M. A. (2005). A meta-analytic test of the challenge stressor-hindrance stressor framework: An explanation for inconsistent relationships among stressors and performance. Academy of Management Journal, 48, 764-775. doi:10.5465/AMJ.2005 18803921

*Lin, S. H. (2004). The management tactics for the influence tactics of perceptions of organizational politics. Unpublished master's thesis, National sun Yat-Sen University.

*Linton, L. (2003). Explaining the relationship between politics perceptions and organizational citizenship behaviours: A dimensional approach. Unpublished master's thesis, Central Michigan University.

Lipsey, M. W., \& Wilson, D. B. (2001). Practical meta-analysis. Thousand Oaks, CA: Sage.

"Liu, Y., Liu, J., \& Wu, L. (2010). Are you willing and able? Roles of motivation, power, and politics in career growth. Journal of Management, 36, 1432-1460. doi:10.1177/0149206309359810

*Miller, B. K., \& Nicols, K. M. (2008). Politics and justice: A mediated moderation model. Journal of Managerial Issues, 20, 214-237.

Miller, B. K., Rutherford, M. A., \& Kolodinsky, R. W. (2008). Perceptions of organizational politics: A meta-analysis of outcomes. Journal of Business and Psychology, 22, 209-222. doi:10.1007/s10869-0089061-5

*Millward, J. E. (1992). The moderating effects of understanding and control on the relationship between perceived organizational politics and job anxiety. Unpublished master's thesis, University of North Carolina, Charlotte.

*Parker, C., Dipboye, R., \& Jackson, S. (1995). Perceptions of organizational politics: An investigation of antecedents and consequences. Journal of Management, 21, 891-912. doi:10.1177/014920639502100505

*Philips, C. U. (2004). An assessment of the factors that affect the level of perceptions of office politics. Unpublished doctoral dissertation, Lynn University, FL.

*Poon, J. M. L. (2003). Situational antecedents and outcomes of organizational politics perceptions. Journal of Managerial Psychology, 18, 138-155. doi:10.1108/02683940310465036

*Poon, J. M. L. (2004). Moderating effect of perceived control on perceptions of organizational politics outcomes. International Journal of Organization Theory and Behaviour, 7, 22-40.

*Poon, J. M. L. (2006). Trust-in-supervisor and helping coworkers: Moderating effect of perceived politics. Journal of Managerial Psychology, 21, 518-532. doi:10.1108/02683940610684373

*Ram, P., \& Prabhakar, G. V. (2010). Leadership styles and perceived organizational politics as predictors of work related outcomes. European Journal of Social Sciences, 15, 40-55.

"Randall, M. L., Cropanzano, R., Bormann, C. A., \& Birjulin, A. (1999). Organizational politics and organizational support as predictors of work attitudes, job performance, and organizational citizenship behaviour. Journal of Organizational Behaviour, 20, 159-174. doi:10.1002/ (SICI) 1099-1379(199903)20:2<159::AID-JOB881>3.0.CO;2-7

Rhoades, L., \& Eisenberger, R. (2002). Perceived organizational support: A review of the literature. Journal of Applied Psychology, 87, 698-714. doi:10.1037/0021-9010.87.4.698

Rodell, J. B., \& Judge, T. A. (2009). Can "good" stressors spark "bad" behaviors? The mediating role of emotions in links of challenge and hindrance stressors with citizenship and counterproductive behaviors. Journal of Applied Psychology, 94, 1438-1451. doi:10.1037/a0016752

Romm, T., \& Drory, A. (1988). Political behaviour in organizations: A cross-cultural comparison. International Journal of Value Based Management, 1, 97-113. doi:10.1007/BF03184886

*Rosen, C. C. (2006). Politics, stress, and exchange perceptions: A dual process model relating organizational politics to employee outcomes. Unpublished doctoral dissertation, University of Akron.

*Rosen, C. C., Chang, C., Johnson, R. E., \& Levy, P. E. (2009). Perceptions of the organizational context and psychological contract breach: Assessing competing perspectives. Organizational Behaviour and Human Decision Processes, 108, 202-217. doi:10.1016/j.obhdp.2008.07.003

*Rosen, C. C., Chang, C., \& Levy, P. E. (2006). Personality and politics perceptions: A new conceptualization and illustration using OCBs. In E. Vigoda Gadot \& A. Drory (Eds.), Handbook of organizational politics (pp. 29-52). Cheltenham, UK: Edward Elgar Publishing House.

*Rosen, C. C., Harris, K. J., \& Kacmar, K. M. (2009). The emotional implications of organizational politics: A process model. Human Relations, 62, 27-57. doi:10.1177/0018726708099836

*Rosen, C. C., Levy, P. E., \& Hall, R. J. (2006). Placing perceptions of politics in the context of the feedback environment, employee attitudes, and job performance. Journal of Applied Psychology, 91, 211-220. doi:10.1037/0021-9010.91.1.211

Rosenthal, R. (1979). The "file drawer problem" and tolerance for null results. Psychological Bulletin, 86, 638-641. doi:10.1037/0033-2909.86 .3 .638

Ryan, R. M., \& Deci, E. L. (2000). Self-determination theory and the facilitation of intrinsic motivation, social development, and well-being. American Psychologist, 55, 68-78. doi:10.1037/0003-066X.55.1.68

*Salimäki, A., \& Jämsén, S. (in press). Perceptions of politics and fairness in merit pay. Journal of Managerial Psychology.

"Schat, A. C. H. (2004). In praise of intolerance: Investigating the effects of organizational tolerance on the incidence and consequences of work- 
place aggression. Unpublished doctoral dissertation, University of Guelph.

Schaufeli, W., \& Bakker, A. B. (2004). Job demands, job resources, and their relationship with burnout and engagement. Journal of Organizational Behavior, 25, 293-315. doi:10.1002/job.248

*Siron, R., Siron, S., Sudin, S., \& Ramayah, T. (2003, September). Factors associated with perceptions of organizational politics in the government higher education institutions. Paper presented at Asian Academy of Management conference, Malaysia.

Spreitzer, G. M., \& Sonenshein, S. (2004). Toward the construct definition of positive deviance. American Behavioural Scientist, 47, 828-847.

Stinglhamber, F., De Cremer, D., \& Mercken, L. (2006). Perceived support as a mediator of the relationship between justice and trust. Group \& Organization Management, 31, 442-468. doi:10.1177/ 1059601106286782

*Tam, W. W. (1998). An assessment of the relationships among organizational trust, organizational politics, and organizational justice, and their effects on merit pay outcomes in the Malaysian public sector. Unpublished master's thesis, The Pennsylvania State University.

"Treadway, D. C., Ferris, G. R., Perrewe, P., Witt, L. A., \& Goodman, J. M. (2005). The role of age in the perceptions of politics-job performance relationship: A three-study constructive replication. Journal of Applied Psychology, 90, 872-881. doi:10.1037/0021-9010.90.5.872

*Valle, M. (1995). Individual determinants of organizational politics: Perceptions and actions. Unpublished doctoral dissertation, Florida State University.

"Valle, M., Kacmar, K. M., \& Zivnuska, S. (2003). Self-efficacy, outcome expectations, and organizational politics perceptions. Journal of Behavioural and Applied Management, 5, 13-23.

*Valle, M., \& Perrewe, P. L. (2000). Do politics perceptions relate to political behaviours? Human Relations, 53, 359-386. doi:10.1177/ 0018726700533004

*Valle, M., \& Witt, L. A. (2001). The moderating effect of teamwork perceptions on the organizational politics-job satisfaction relationship. The Journal of Social Psychology, 141, 379-388. doi:10.1080/ 00224540109600559

*Valle, M., Witt, L. A., \& Hochwarter, W. (2002). Dispositions and organizational politics perceptions: The influence of positive and negative affectivity. Journal of Management Research, 2, 121-128.

*Vechpong, T., \& Boonyam, T. (2007). Moderating effect of internal locus of control on the relationship between perceived administrative behaviour of leaders and perceived organizational politics. The Journal of Behavioural Science, 2, 32-40.

*Vigoda-Gadot, E. (2000). Organizational politics, job attitudes and work outcomes: Exploration and implications for the public sector. Journal of Vocational Behaviour, 57, 326-347.

*Vigoda-Gadot, E. (2001). Reactions to organizational politics: A crosscultural examination in Israel and Britain, Human Relations, 54, 14831518.

*Vigoda-Gadot, E. (2002). Stress-related aftermaths to workplace politics: An empirical assessment of the relationship among organizational politics, job stress, burnout, and aggressive behaviour. Journal of Organizational Behaviour, 23, 571-591.

*Vigoda-Gadot, E. (2007). Redrawing the boundaries of OCB? An empirical examination of compulsory extra-role behaviour in the workplace. Journal of Business and Psychology, 21, 377-405.
*Vigoda-Gadot, E., \& Cohen, A. (2002). Influence tactics and perceptions of organizational politics: A longitudinal study. Journal of Business Research, 55, 311-324.

*Vigoda-Gadot, E., \& Kapun, D. (2005). Perceptions of politics and perceived performance in public and private organisations: A test of one model across two sectors. Policy and Politics, 33, 251-276.

*Vigoda-Gadot, E., \& Meisler, G. (2010). Emotions in management and the management of emotions: The impact of emotional intelligence and organizational politics on public sector employees. Public Administration Review, 70, 72-86.

*Vigoda-Gadot, E., Peretz, H. V., \& Zion, E. B. (2003). Politics and image in the organizational landscape. An empirical examination among public sector employees. Journal of Managerial Psychology, 18, 764-787.

Wallace, J. C., Arnold, T., Edwards, B. D., Frazier, M. L., \& Finch, D. M. (2009). Work stressors, role-based performance, and the moderating influence of organizational support. Journal of Applied Psychology, 94, 254-262.

Willness, C. R., Steel, P., \& Lee, K. (2007). A meta analysis of the antecedents and consequences of workplace sexual harassment. Personnel Psychology, 60, 127-162.

*Witt, L. A. (1998). Enhancing organizational goal congruence: A solution to organizational politics. Journal of Applied Psychology, 83, 666-674.

*Witt, L. A., Andrews, M. C., \& Kacmar, K. M. (2000). The role of participative decision making in the organizational politics-job satisfaction relationship. Human Relations, 53, 341-357.

*Witt, L. A., Kacmar, K. M., Carlson, D. S., \& Zivnuska, S. (2002). Interactive effects of personality and organizational politics on contextual performance. Journal of Organizational Behaviour, 23, 911-926.

"Witt, L. A., Patti, A. L., \& Farmer, W. L. (2002). Organizational politics and work identity as predictors of organizational commitment. Journal of Applied Social Psychology, 32, 486-499.

*Witt, L. A., Treadway, D. C., \& Ferris, G. R. (2004). The role of age in reactions to organizational politics perceptions. Organizational Analysis, $12,39-52$

Wong, C. S., \& Law, K. S. (2002). The effects of leader and follower emotional intelligence on performance and attitude: An exploratory study. The Leadership Quarterly, 13, 243-274.

"Wraalstad, K. J. (1992). The construct validity of perceptions of organizational politics scale. Unpublished master's thesis, University of Wisconsin, Oshkosh.

${ }^{*} \mathrm{Wu}, \mathrm{M} . \mathrm{H}$. (2004). The outcome of organizational politics and the tactics of management. Unpublished master's thesis, National sun Yat-Sen University.

*Yen, W. W., Chen, S. C., \& Yen, S. I. (2009). The impact of perceptions of organizational politics on workplace friendship. African Journal of Business Management, 3, 548-554.

*Zellars, K. L., \& Fiorito, J. (1999). Evaluations of organizational effectiveness among HR managers: Cues and implications. Journal of Managerial Issues, 11, 37-55.

Zhou, J., \& Ferris, G. R. (1995). The dimensions and consequences of organizational politics perceptions: A confirmatory analysis. Journal of Applied Social Psychology, 25, 1747-1764.

Received June 14, 2013

Revision received August 22, 2013

Accepted August 27, 2013 